\title{
O Rosto Humano de Deus nas Vítimas Ética, Mística e Profecia na Teologia de Jon Sobrino
}

Orientador: Paulo Fernando Carneiro de Andrade

Mestrando: Ana Márcia Santana de Oliveira

Área de Concentração: Teologia Sistemático-Pastoral

Linha de Pesquisa: Religião e Modernidade

O Deus de Jesus Cristo nos convoca sempre a optar pelas vítimas deste mundo. Nosso trabalho acadêmico concentra-se na esperança das mesmas e na promessa de resgatá-las como chave de leitura hermenêutica teológica. Aspirase reconhecer que na Teologia de Jon Sobrino existe uma urgente necessidade do zelo teológico centrado no mistério da presença misericordiosa de Deus na história. Neste sentido, amplia-se o olhar para os novos rostos de vítimas na realidade Latino-Americana e Caribenha que emergem da Globalização. E com a convicção de que "fazer teologia a partir de testemunhas enriquece e aprofunda a teologia de textos", o ensejo é registrar e aclamar "o rosto humano de Deus nas vítimas, enfocando a ética, a mística e a profecia à luz da teologia de Jon Sobrino".

Palavras-chave: Reino de Deus; Princípio Misericórdia; Realidade; Ética; Opção pelas Vítimas; Profecia; Mística; Mistagogia; Martírio; Teologia da Libertação. 